\title{
Islamophobia and Twitter: A Typology of Online Hate Against Muslims on Social Media
}

The Woolwich attack in May 2013 has led to a spate of hate crimes committed against Muslim communities in the United Kindom. These incidents include Muslim women being targeted for wearing the headscarf and mosques being vandalized. While street level Islamophobia remains an important area of investigation, an equally disturbing picture is emerging with the rise in online anti-Muslim abuse. This article argues that online Islamophobia must be given the same level of attention as street level Islamophobia. It examines 500 tweets from 100 different Twitter users to examine how Muslims are being viewed and targeted by perpetrators of online abuse via the Twitter search engine, and offers a typology of offender characteristics.

KEY WORDS: anti-Muslim prejudice, cyber hate, hate crime, Islamophobia, online hate

\section{Introduction}

In May 2013, Michael Adebowale and Michael Adebolajo murdered British soldier Lee Rigby in Woolwich, south-east London. The men ran him over in a car before using knives and a meat cleaver to attack and murder him. Adebowale and Adebolajo were convicted of the murder of Lee Rigby in December 2013. At the time, the incident provoked strong public anger and outrage by politicians, policymakers and the media. British Prime Minister David Cameron argued that the Woolwich attack would not "divide us" but instead make us "stronger" in the fight against global and home-grown terrorism. However, the tragic events of that day also led to a series of attacks against Muslims, mosques (BBC News, 2013a), and Islamic institutions, amounting to a sharp increase in Islamophobia-related incidents (BBC News, 2013b). Indeed, a number of police forces saw a dramatic surge in the number of reported hate crimes against Muslims, with the Metropolitan police recording 500 Islamophobic crimes, since Woolwich (The Guardian, 2013). While a number of these incidents took place offline (i.e., with the use of direct physical force; Saul, 2013) there were also people who used social media sites to either vent their anger or to make actual death threats against Muslim communities (BBC News, 2013c). Clearly, major incidents such as the Woolwich attack can provoke public outrage, anger, and can lead to stereotyping of all Muslim communities as being violent extremists (Larsson, 2007). Indeed, the Internet and social media sites such as Twitter have become a popular arena for online hate, partly due to their accessibility and the anonymity they offer for offenders who use it to intimidate, harass, and bully others (Christopherson, 2007). Following the Woolwich attack, we have seen how Twitter was used by offenders who promoted this type of online Islamophobic hate, including tactics of harassment and threats of reprisal attacks (BBC News, 2013c) (Figure 1).

Online anti-Muslim abuse occurring on social networking sites, such as Twitter, can be categorized as being "cyber harassment," "cyber bullying," "cyber abuse," "cyber incitement/threats," and "cyber hate" (Wall, 2001). Many of the comments posted online through social networking sites have an extremist and 
incendiary undertone. Moreover, they are not confined to social networking sites and include blogging sites, online chat rooms, and other virtual platforms that can be used to promote online cyber hate and Islamophobia (Allen, 2014), often in the form of racist jokes and stereotypical "banter" (Weaver, 2013). If these incidents go unchecked, this type of negativity can also lead to an escalation of online abuse and the normalization of such behavior, including physical attacks (Allport, 1954). For example, a number of sites such as the http://anti-islam.blogspot.co.uk/ (Anti-Islam Blog, 2013) and http://www.jihadwatch.org/ aim to tackle what they call the "anticivilization of Islam." While many of these blogs and websites use the cloak of freedom of expression to perpetuate an anti-Muslim rhetoric, it inevitably attracts users who are quick to post comments on pieces that have a deeply embedded antiMuslim narrative (JihadWatch, 2013).

Clearly, online abuse is not restricted to online Islamophobia, for example, it could be online anti-Semitic abuse, racist abuse, homophobic abuse, gender-based abuse and antidisability abuse, 1 however this article aims to shed light on this phenomenon, which following the Woolwich attack had become the prime focus for the British police force and other similar agencies that investigate online hate crime. Statistics from the police and organizations such as Tell Measuring Anti-Muslim Attacks (MAMA) report a significant increase in the number of people reporting online anti-Muslim abuse to them (Tell MAMA, 2013). Feldman, Littler, Dack, and Copsey (2013, p. 21) found that: "The majority of the incidents of Muslim hate crime reported to Tell MAMA are online incidents and 300-69 percent-of these online cases reported a link to the far right," specifically to the English Defence League (EDL) and the British National Party (BNP).2 They also found that most of the online hate reported to Tell MAMA was committed by males, and that some of the online hate incidents also included threats of offline action. Feldman et al. (2013, p. 23) state that a number of online incidents reported included direct threats from burning down mosques to killing Muslim babies. They state that: "Racist remarks were, in turn, mainly anti-Pakistani comments and references to dirt and filth. More generally there were comments accusing Muslims of rape; paedophilia; incest; interbreeding; being terrorists; and killing Jews" (Feldman et al., 2013, p. 23). 


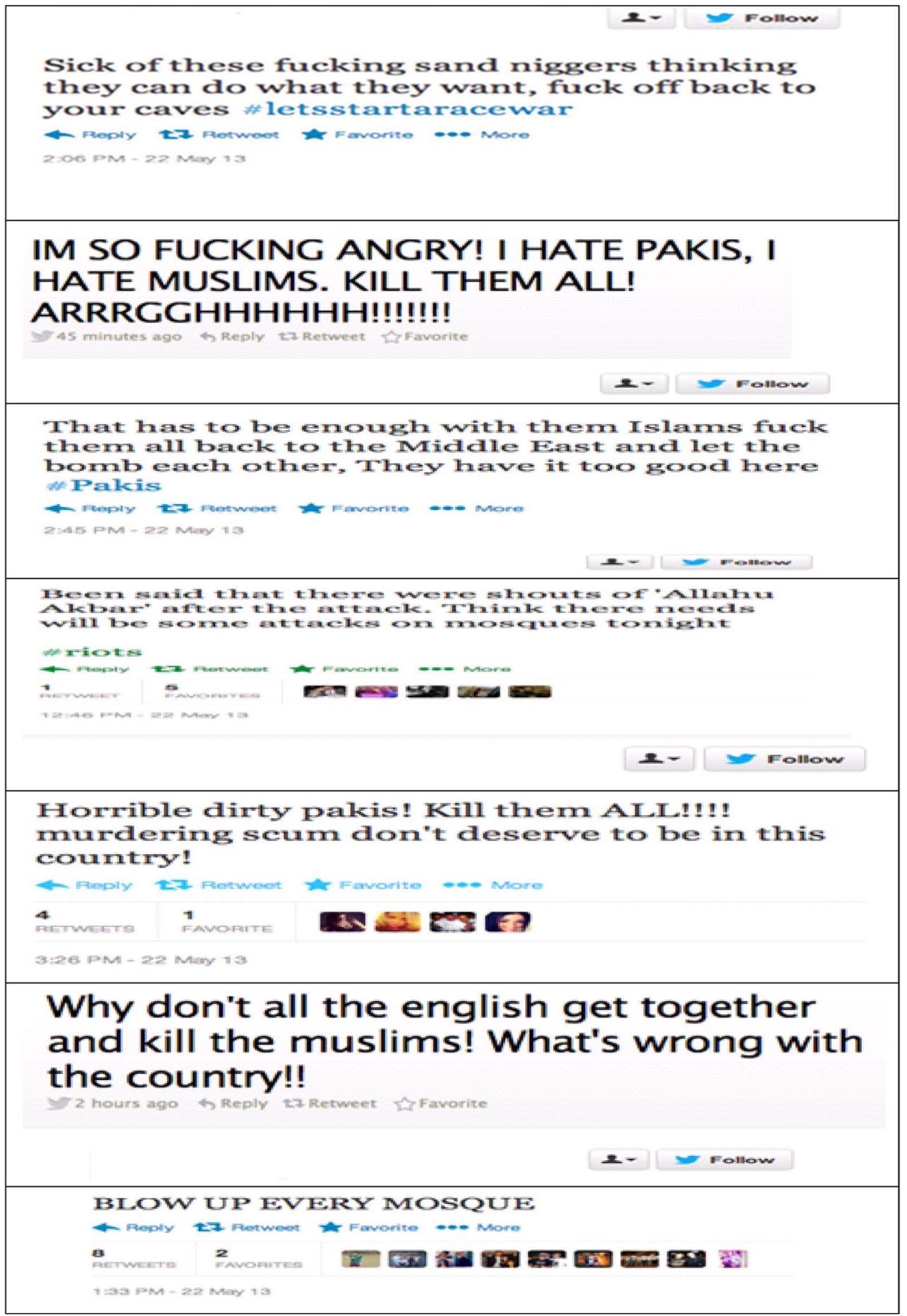


Figure 1. Selection of Tweets Following the Woolwich Attack, Which Can Also Be Accessed via http://publicshaming.tumblr.com/search/woolwich. All Tweets Have Been Anonymized.

These facts are not isolated, as the UK's Association of Chief Police Officers (ACPO), also revealed a similar trend that saw them receive 136 complaints of online anti-Muslim abuse, coinciding with the immediate aftermath of the Woolwich attack and reported through its "True Vision" website which deals with hate crimes following the death of Lee Rigby (ACPO, 2013). True Vision is the UK police's main cyber tool in tackling online hate. It examines illegal content that threatens or harasses a person or group of persons because of hostility toward their race, religion, sexual orientation, disability, or transgender. It notes, however that: "Most hateful or violent website content is not illegal" and gives victims of online hate three options in dealing with the incident (True Vision, 2013). These include reporting the material to the police, reporting the material to a hosting company, or contacting the website administrator to remove the material (True Vision, 2013).

This article examines 500 tweets, from 100 different Twitter users, to try and find out how Muslims are viewed by perpetrators of online abuse, who are targeting them through social media sites such as Twitter. All of the tweets were analyzed between January 2013 and April 2014, and are available and accessible in the open public domain. The overwhelming number of tweets were written and posted by people who were living in the United Kingdom, although there were some tweets from users who were based in Australia and the United States. From the data collected, the majority of tweets (72 percent) were posted by males. Three hashtags (\#Woolwich, \#Muslim, and \#Islam) were used to examine patterns emerging regarding online Islamophobia on Twitter, having appeared on the Twitter search engine as words that had recently "trended" in the United Kingdom. For example, on September 11, 2013, the hashtag \#FuckMuslims was trending (Figure 2). Following this, the article provides a typology of offender characteristics. To my knowledge, this is the first study to examine online Islamophobia via Twitter and provides a typology, therefore making an important contribution to help us understand the role of Islamophobia on social media network sites, such as Twitter. 


\begin{tabular}{|c|}
\hline 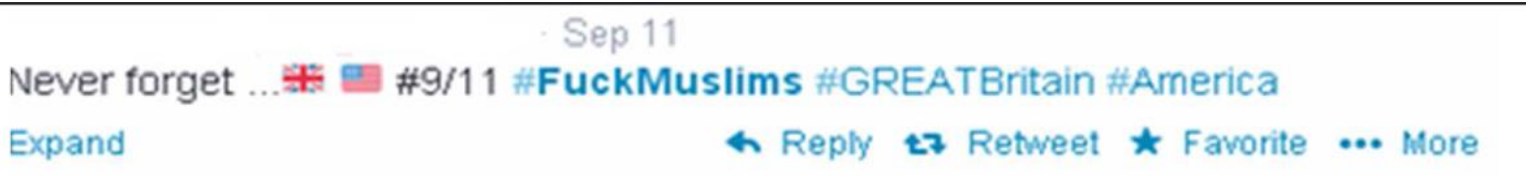 \\
\hline $\begin{array}{l}\text { \#TweetLikeAWhitePerson my fish just drowned \#FuckMuslims } \\
\text { Expand } \quad \text { h Reply } 27 \text { Retweet } \star \text { Favorite ... More }\end{array}$ \\
\hline $\begin{array}{l}\text { Guys...two Muslims died } 12 \text { years ago for there religion. I say we take the rest } \\
\text { of em and buttbfuck em with razor blades! \#fuckmuslims \#usa } \\
\text { Expand } \\
\leftarrow \text { Reply } t \text {.7 Retweet } \star \text { Favorite ... More }\end{array}$ \\
\hline $\begin{array}{l}\text { Muslims matching through New York on 9/11???? Yeah you } \\
\text { can all get the FUCK OUT OF THIS COUNTRY \#fuckmuslims" MAN FUCK YOU } \\
\text { Expand } \\
\text { ↔ Reply } t \text { Retweet } \star \text { Favorite } \cdots \text { More }\end{array}$ \\
\hline
\end{tabular}

Figure 2. A Selection of Trending Tweets on September 11, 2013. All Tweets Have Been Anonymized.

Online Islamophobia remains under researched. Indeed, a recent report conducted by Feldman et al. (2013, p. 10) regarding online anti-Muslim prejudice has highlighted how: "The online domain remains under-researched" and "much less attention has been paid to online hate crime, which can be the precursor to more physically threatening offline incidents" (11). As noted above, the debate about Islamophobia is often centered on street-level incidents, including pulling of headscarves and attacks against mosques (Allen, 2010). However, increasingly a number of cases reported to organizations like Tell MAMA include online anti-Muslim abuse directed against Muslim communities, including high profile Muslim figures such as Baroness Warsi (the UK Minister of Faith and Communities) and Jemima Khan (wife of the Pakistani cricketer turned politician, Imran Khan) both of whom were subjected to online threats which were reported to the police by Tell MAMA (Sinha, 2013).

Furthermore, a number of high profile Muslim public figures have also expressed their frustration at the lack of support available for Muslims suffering online abuse. Hasan, the UK political director of The Huffington Post, recalls the impact of online anti-Muslim hate comments made against him:

To say that I find the relentlessly hostile coverage of Islam, coupled with the personal abuse that I receive online, depressing is an understatement. There have been times-for instance, when I found my wife curled up on our couch, in tears, after 
having discovered some of the more monstrous and threatening comments on my New Statesman blog-when I've wondered whether it's all worth it (Hasan, 2012)

These comments are not isolated; other Muslims in the public eye such as Inayat Bunglawala, Huma Qureshi, and Nadiya Takolia have all described the online abuse they have suffered, including the following:

...the true face of pakiland is the cleansing of Hindu and Sikh minorities since 1948, and the ongoing deceptions practiced by Pakistanis, not some fluff piece about an honest man. Exception to the rule. There is a lamppost and noose waiting for every jihadi that comes back to Britain and their scum enables and sympathizers... (Bunglawala, 2012)

Clearly, the above "hate" comments made online can have a negative impact on the victims targeted, and can be very upsetting and unsettling for them and their families (Bunglawala, 2012). Evidence from Feldman et al. (2013) also suggests that post Woolwich, the Internet and social networking sites have been used by far-right groups such as the EDL to promote online cyber hate attacks against Muslim communities. This type of prejudice follows a "drip drip" effect, which has intensified (Feldman et al., 2013), post Woolwich.

Another problem when dealing with online abuse seems to be the laissez-faire attitude from some of the social media sites such as Twitter who simply ask the victim either to block someone or close their account. In response to the criticisms by Stan Collymore, complaining of online racist abuse, Twitter stated that: "We cannot stop people from saying offensive, hurtful things on the Internet or on Twitter. But we take action when content is reported to us that breaks our rules or is illegal" (BBC News, 2014). While cyberspace can be a safe environment for some offenders, internal and external mechanisms are equally required to support victims of online hate (Sayyed \& Vakil, 2011). This article argues that online anti-Muslim hate therefore requires a multifaceted and international approach from different agencies, including the police, social networking sites, and a government-led approach that tackles online Islamophobia as a rising phenomenon.

\section{Background and Context}

Recent threats made against the former UK Member of Parliament, the Respect Leader, Salma Yaqoob, have reinforced the problem of online antiMuslim abuse. After appearing on the television program BBC Question Time in 2013, Salma Yaqoob tweeted the following comments to her followers: "Apart from this threat to cut my throat by \#EDL supporter (!) overwhelmed by warm response to what I said on \#bbcqt." The person arrested in connection with the comments, Steve Littlejohn, had threatened Salma Yaqoob, stating that: "if that salma yaqueb's there, cut her f\#\#\# throat, rip weyman bennets teeth out with pliers and carve EDL across all the Asian scum who try and attack us"

(Birmingham Mail, 2013).

Clearly, threatening and abusive comments, whether it be by visual images, fake profiles, Facebook messages, online YouTube videos and tweets such as the above, 
can have a detrimental effect on the victims who are targeted, and their families (Waddington, 2010). What the above case demonstrates is that online behavior can be normalized by offenders, which allows a perpetrator to use in many cases anonymity, manipulation, and social control to target their victims (Douglas et al., 2005). However, while this form of cyber hate often remains invisible, sometimes due to offenders deleting tweets and also because the perpetrator can hide their identity, the threat remains very real for the victims it targets (Hall, 2005). Indeed, trying to ascertain all the potential threats and risks posed online poses a major challenge for the security services, the police, and the government. Cyber hate within the policing context therefore requires due diligence and an investigation that determines potential online offenders, offensive tweets, and those they believe can be prosecuted according to the UK's Crown Prosecution Service (CPS) rules.

Communications via social media sites, like Twitter, can be a criminal offense. The CPS guidelines state that there must be either: a credible threat of violence; communications which specifically target an individual or group of people; communications which amount to a breach of a court order; or communications which may be considered grossly offensive, indecent, obscene or false (CPS, 2014). In many of these cases people can be charged for comments made via social networking sites under "racially motivated" or "religiously motivated" crimes through the Crime and Disorder Act 1998, the Malicious Communications Act 1988, the Communications Act 2003, and the Public Order Act 1986 (Coliandris, 2012). Overall, policing Twitter and people's activity via social media sites remains difficult, and the recent Leveson Inquiry (2012) in the United Kingdom, set up by the UK government to investigate the culture, practices and ethics of the Press also acknowledges that it is problematic to regulate.

Despite this, following Woolwich a number of arrests were made where people had posted comments on Twitter and Facebook that were deemed to incite racial hatred or violence. In one case, a person was convicted under the Malicious Communications Act 1988, after an offensive message was posted on Facebook (Urquhart, 2013). Cyber hate regulation therefore requires the police and other agencies to act quickly and more effectively in relation to online Islamophobic abuse. At the moment, it appears that social media sites such as Twitter resemble a virtual minefield of hate, and therefore policing it requires a new process of educating people of the dangers of online abuse and providing victims with support (Chan, 2007).

\section{What Is Cyber Hate and Online Islamophobia?}

There is no universal definition of a hate crime; instead we have a myriad of interpretations, which include statements or terms aimed at targeting a person or person(s) because of their particular religion, gender, race, sexual orientation, physical or mental disability, and ethnicity. Cyber hate, therefore, is the nexus of those communications and concepts where a perpetrator utilizes electronic technology and the convergence of space, movement and behavior in a "safe" virtual environment to "control" and target "opponents" considered to be a threat (Awan \& Blakemore, 2012). This type of control allows the perpetrator to act in a dominant way against groups they deem to be subordinate; often in the case of Muslims, by attacking their faith and ethnicity (Perry, 2001). 
It also allows offenders to use the online world and other social networking platforms to target individuals they deem to be "different" from them both in an ideological, political, and religious sense (Taras, 2012). As noted above, cyber hate is a complex phenomenon and is used to promote a particular ideology that promotes racial hatred, religious intolerance, and also allows "lone wolfs" and "hate groups" to exert power and social control in a systematic and targeted manner that has no respect for a victim's rights (Perry, 2001). Academics looking at the psychology of online offenders have also argued that such people have an inherent problem around their own personal identity, whereby the use of the Internet becomes a safe haven for them and creates a sense of anonymity, allowing them to use and exploit social and political beliefs as an ideology that has no respect for the individuals or groups it targets. This can therefore result in them trying to use online methods as a means of self-protectionism and false patriotism, as for groups like the far right, which fuel antiMuslim hate and abuse (Cole \& Cole, 2009).

This can also often be played out by abusive, threatening, and coordinated tweets or through the use of sites like Twitter to send messages of hate, including the use of visual images to target particular individuals (Whine, 2003). Clearly, it should be noted that the Internet can also be an extremely valuable tool in helping detect and tackle online cyber crime, and increasingly is being used by the police to help engage with communities. Blakemore (2013), for example, argues that the use of social networking sites by the police can have an important impact on people's level of "fear of cyber crime" and also can help assist them report such incidents to the police.

The Runnymede Trust (1997) has identified eight components that they define as constituting Islamophobia. They include where people view: (i) Islam as a faith that is unresponsive to change; (ii) where the values of Islam appear not to be compatible with other cultures and faiths; (iii) Islam is viewed as being a religion that is barbaric and sexist; (iv) Islam is also seen as being a religion that is both violent and aggressive; (v) Islam is viewed as a political ideology; (vi) Islam and criticisms made about the faith are unwarranted; (vii) discriminatory practices are used to justify exclusion of Muslim communities; and (viii) anti-Muslim crime is seen as normal.

Interestingly, very little discussion is made of online Islamophobia. They argue that Islamophobic views is shaped by a "closed set" of narrow views on Islam and Muslims, which has helped contribute to the "othering" of Muslim communities through discriminative practices and affects (Awan, 2012). The Forum against Islamophobia and Racism (2013) argues that Islamophobia constitutes fear and hostility against Muslim communities. However, like the above interpretations, they confine Islamophobia to physical attacks such as abuse and targeted violence against Muslim communities, mosques, cemeteries, and discrimination in places of education (Allen, 2001).

While these definitions remain limited in scope with regard to the online dimension of Islamophobia, they do however give us a starting point for further discussion and discourse in this area. I argue here, however, that we need a separate definition of online Islamophobia, which is recognizable both at a policy level and an academic level. For example, a definition which includes: "Anti-Muslim hate is prejudice that targets a victim in order to provoke, cause hostility and promote intolerance through 
means of harassment, stalking, abuse, incitement, threatening behavior, bullying and intimidation of the person or persons, via all platforms of social media" could be used as a means to help assist the police.

\section{Methodology and Findings}

This article examines how Muslims are being viewed via one main social media platform, namely Twitter. Five hundred tweets are analyzed to look for patterns emerging about Muslim communities on this social media platform. The research questions in this article include:

How is Twitter being used to describe and view Muslims?

What content is being used via Twitter to demonize and stereotype Muslims?

What physical and nonphysical threats are being used against Muslims via Twitter?

This article uses a mixed methodology as part of a wider content analysis utilizing qualitative and quantitative data gathering techniques embedded within grounded theory. The tweets were analyzed between January 2013 and April 2014, using the hashtags \#Woolwich, \#Muslim, and \#lslam in order to examine patterns emerging regarding online Islamophobia on Twitter. Hashtags allow an opportunity to use specific terms such as Muslim and Islam, as a means to see how Muslims were depicted both before and post Woolwich (indeed, these terms had appeared on the Twitter search engine as words that had recently "trended" in the United Kingdom). This enabled the researcher to collect a random sample of 500 tweets from 100 different Twitter user profiles. As noted previously, the overwhelming number of tweets were written and posted by people in the United Kingdom, although there were some tweets from users who were based in Australia and the United States. The majority of tweets were posted by males (72 percent). There were a number of terms that were used to describe Muslims in a negative manner, however some of the most common reappearing words used to describe Muslims in a derogatory way were also examined (Figure 3); these included the words Muslim pigs (9 percent), Muzrats (14 percent), Muslim Paedos (30 percent), Muslim terrorists (22 percent), Muslim scum (15 percent), and Pisslam (10 percent).

Tell MAMA, which measures anti-Muslim hate attacks also examined the use of words on social media to describe Muslims from January 2013 to December 2013, collating high-frequency words that were directly related to anti-Muslim hate and prejudice. They also (similarly) found the words Ninja, Muzrats, and Paedo being used against Muslims (Tell MAMA, 2014). After examining the 500 tweets, and looking at the use of language to depict Muslims in a negative light, a typology was constructed, consisting of eight different people identified as cyber trolls; that is, people who are using social networking sites such as Twitter to produce a sustained campaign of hate against Muslim communities. Examples of these tweets are shown in Figure 4. 


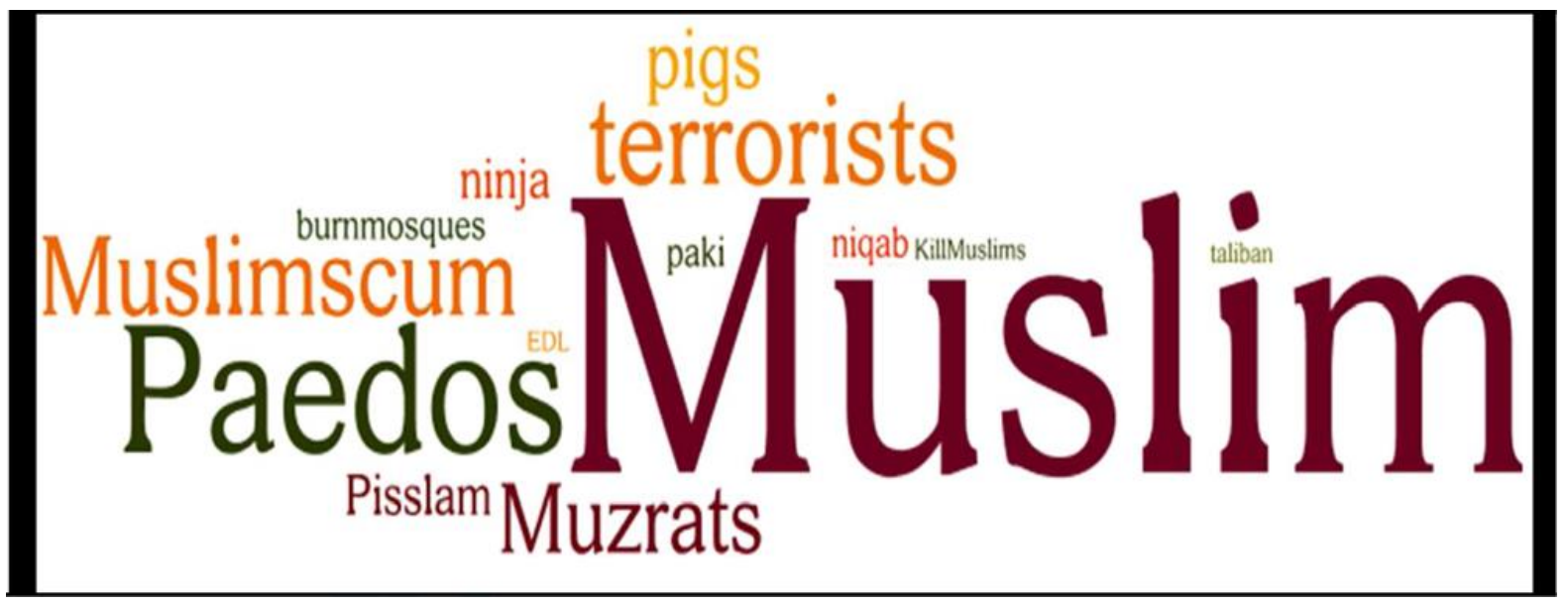

Figure 3. Word Cloud of Most Frequent Posts of Anti-Muslim Prejudice From Twitter. Awan: Islamophobia and Twitter 141 


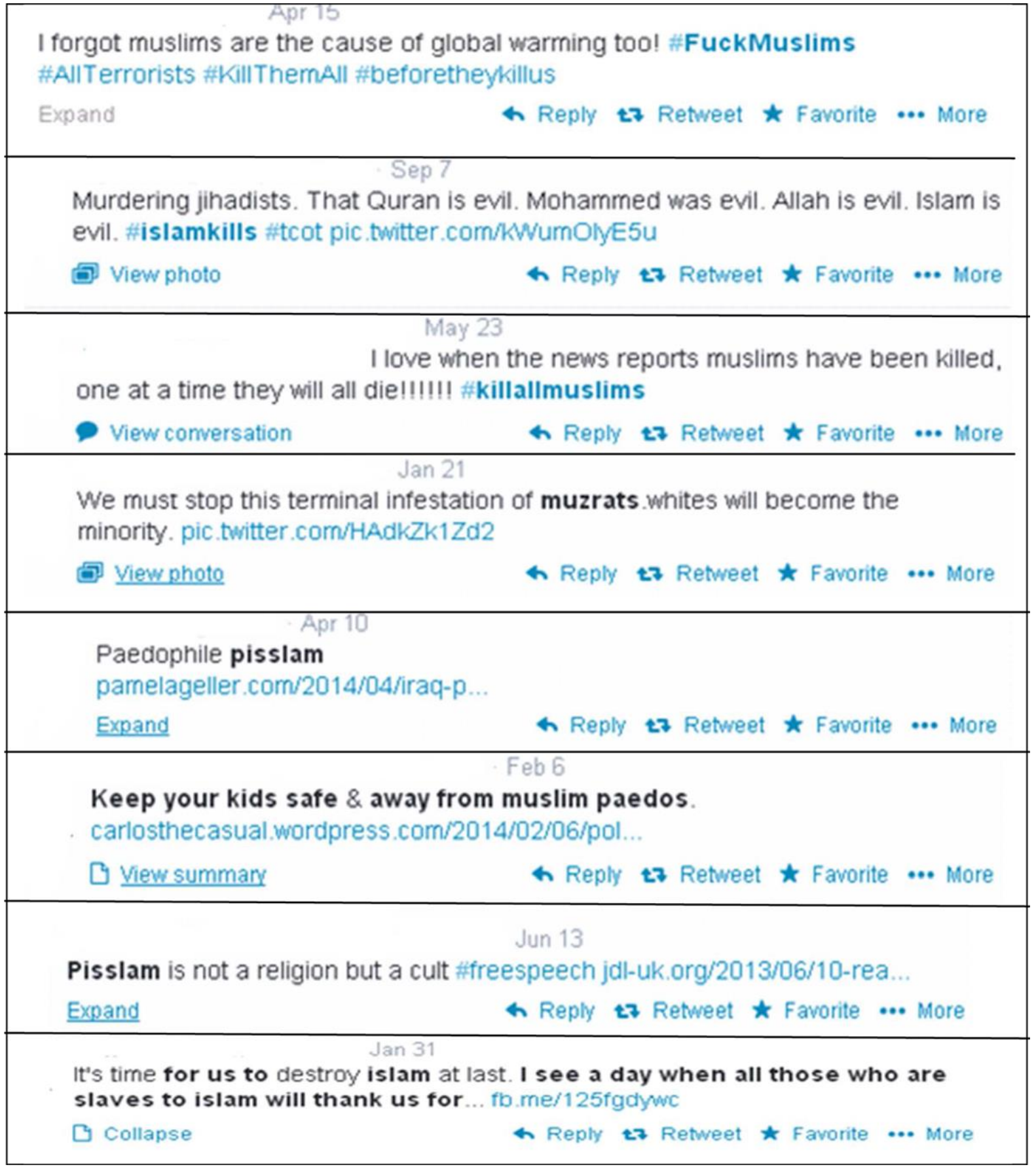

Figure 4. A Selection of Tweets Examined in the Article.

\section{A Typology of Online Perpetrators}

Over 75 percent of the tweets examined showed a strong Islamophobic feeling, used to stereotype and blame all Muslims on a particular issue, used to justify the abuse. For example, some accounts were open about their anger and hatred for Muslims as a result of recent cases surrounding Asian men convicted of grooming underage 
girls. Moreover, a number of accounts also used and disseminated anti-Muslim images and literature as a means to defame and caricature Muslims as dangerous pedophiles. Indeed, the word Muslim Paedos was used up to 30 percent of times, reflecting and coinciding with recent cases of Muslim men convicted of grooming offenses (Greenwood, 2013). However, in some cases people simply used Twitter as a means to antagonize and create hostility with some accounts using derogatory terminology by referring to Muslims as Muzrats (a demeaning word to describe Muslims as vermin or comparing them to a disease). Some tweets used a number of hostile hashtags to note how \#lslamkills and whites would become a minority unless the Muzrats are stopped. Interestingly, the word \#Muslimterrorists also appeared high on the list of frequent words used, accounting for 22 percent. In particular, it became part of the September 11 trending words across Twitter where Muslims were being depicted through pictures and videos as extremists and terrorists.

On the face of it, a number of offenders shared similar characteristics but were different in their approaches to targeting Muslim communities online. Using an online content behavioral offender typology, the tweets were grouped into different categories, to create the following typologies. These are: the trawler (a person who has gone through other people's Twitter accounts to specifically target people with a Muslim connection); the apprentice (someone who is fairly new to Twitter but nonetheless has began to target people with the help of more experienced online abusers); the disseminator (someone who has tweeted about and retweeted messages, pictures, and documents of online hate that are specifically targeting Muslims); the impersonator (a person who is using a fake profile, account, and images to target individuals); the accessory (a person who is joining in with other people's conversations via Twitter to target vulnerable people); the reactive (a person who following a major incident, such as Woolwich, or issues on immigration, will begin an online campaign targeting that specific group and individual); the mover (someone who regularly changes their Twitter account in order to continue targeting someone from a different profile); and finally, the professional (a person who has a huge following on Twitter and regardless of consequences has and will launch a major campaign of hate against an individual or group of people because they are Muslim. This person will also likely to have multiple Twitter accounts all aimed at targeting Muslim communities) (Table 1). 
Table 1. Typology of Offender Characteristics

\begin{tabular}{|c|c|c|}
\hline Type & Characteristics & No. of Cases \\
\hline The trawler & $\begin{array}{l}\text { Someone who has gone through other people's twitter accounts } \\
\text { to specifically target people with a Muslim connection }\end{array}$ & 57 \\
\hline The apprentice & $\begin{array}{l}\text { A person who is fairly new to Twitter but nonetheless has began } \\
\text { to target people with the help of more experienced online } \\
\text { abusers }\end{array}$ & 39 \\
\hline The disseminator & $\begin{array}{l}\text { Someone who has tweeted about and retweeted messages, } \\
\text { pictures, and documents of online hate that are specifically } \\
\text { targeting Muslims }\end{array}$ & 75 \\
\hline The impersonator & $\begin{array}{l}\text { A person who is using a fake profile, account, and images to } \\
\text { target individuals }\end{array}$ & 76 \\
\hline The accessory & $\begin{array}{l}\text { A person who is joining in with other peoples conversations via } \\
\text { Twitter to target vulnerable people }\end{array}$ & 82 \\
\hline The reactive & $\begin{array}{l}\text { A person who following a major incident, such as Woolwich, or } \\
\text { issues on immigration, will begin an online campaign } \\
\text { targeting that specific group and individual }\end{array}$ & 95 \\
\hline The mover & $\begin{array}{l}\text { Someone who regularly changes their Twitter account in order } \\
\text { to continue targeting someone from a different profile }\end{array}$ & 46 \\
\hline The professional & $\begin{array}{l}\text { A person who has a huge following on Twitter and regardless of } \\
\text { consequences has and will launch a major campaign of hate } \\
\text { against an individual or group of people because they are } \\
\text { Muslim. This person will also have multiple Twitter accounts } \\
\text { all aimed at targeting Muslim communities }\end{array}$ & 30 \\
\hline
\end{tabular}

At the heart of each of these different categories, it became clear that the users involved had similar motivations. Some of those were based on seeking authority and power as shown by some tweets from users who used their Twitter account to collect and maximize influence. In such a case, this affords some people the motivation to commit the online abuse and as a result, they are able to target specific people (Iganski, 2012). Figure 5 shows a cycle demonstrating those key characteristics of the cybertroll.

\section{Challenges Around Online Hate and Islamophobia}

As noted previously, online Islamophobia is under researched both at a policy level and an academic level. This article argues that a new cyber hate policy is much needed both at a government level and a policing level, which would be timely considering the recent spike of online anti-Muslim abuse, leading to ACPO receiving over 136 separate incidents following Woolwich (ACPO, 2013). Cyber hate has been used by the far-right and White supremacists, who have used it to inflame religious and racial tensions; a study for the British-based think-tank group Demos (2011) found that far-right populist movements are gaining in support across Europe and playing upon a small perception of public disenfranchisement within society to promote an agenda of protecting national identity as a method to whip up online antiMuslim hate. 


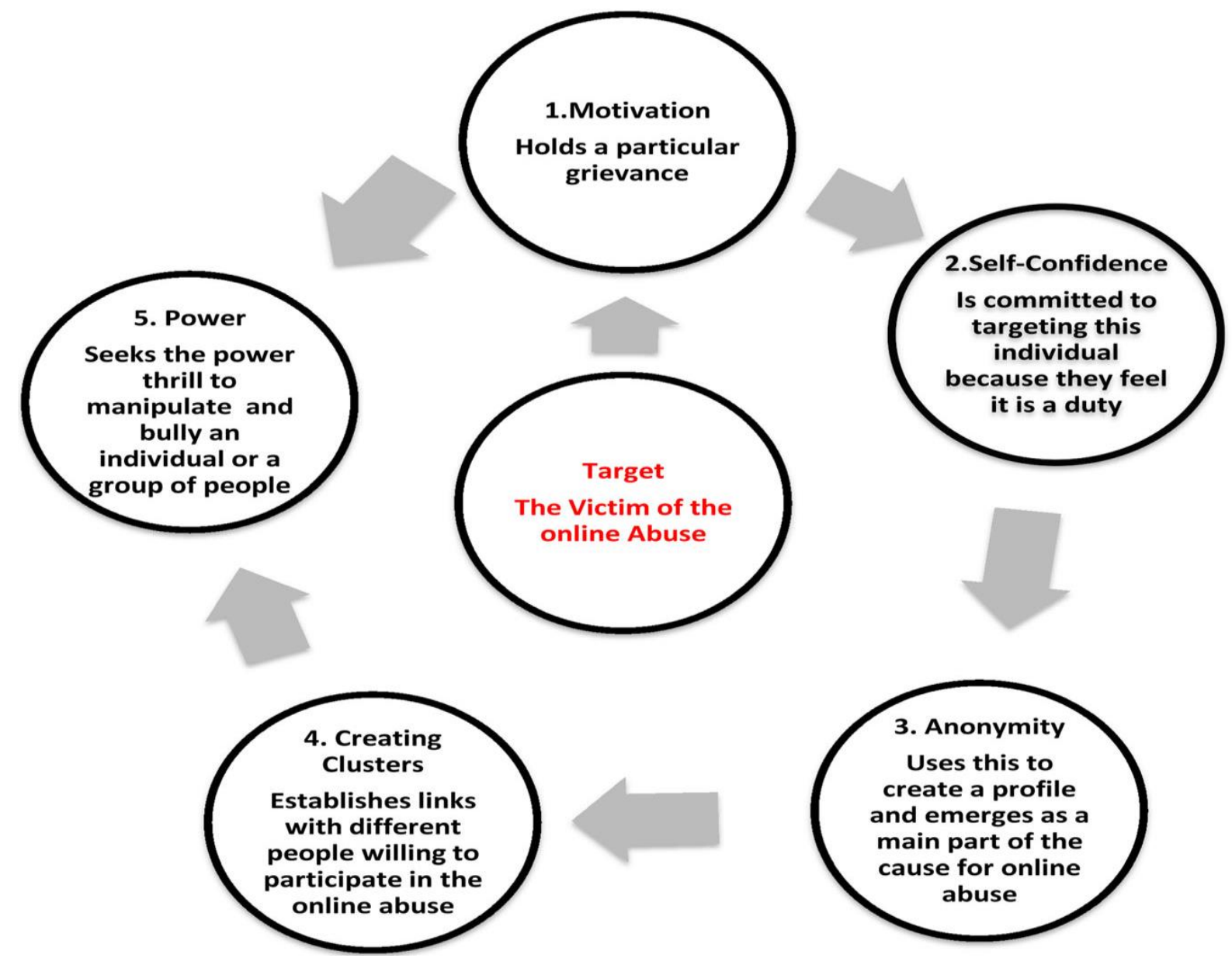

Figure 5. The Cyber Troll: A Cycle of Online Abuse.

The Demos study (2011) is interesting because their findings would seem to suggest that the EDL have become a web-based far-right group that is using social networking sites such as Facebook and Twitter where it has gained a core group of online sympathizers to target Muslim communities (Awan \& Blakemore, 2012). The Demos study found that on a national scale, 72 percent of supporters for the EDL were under the age of 30, and 36 percent of people were aged between 16 and 20; thus reflecting the movement's desire to attract a "younger" audience on social networking sites such as Facebook.

The Online Hate Prevention Centre report (2013) into online Islamophobia searched over 50 different Facebook pages and showed a clear correlation of hate speeches online that were targeted toward Muslims. Overall, they found 349 separate instances of online hate speeches directed against Muslims, including a number of Facebook pages created in order to specifically target Muslim communities. For example, the "Boycott all Halal products in Australia!" page, which has over 520 likes (https://www.facebook.com/pages/boycott-all-halalproducts-in australia/171203192936626), the page "The truth about Islam" which has over 150,000 likes (https://www.facebook.com/ThelslamicThreat), the Islam is Evil page (418 likes) (https://www.facebook.com/IslamlsEvil), and the Prophet Muhammad Still Burns in Hell page which has 470 likes (https://www.facebook.com/pages/TheProphet-Muhammad-STILL-Burns-In-Hell-Fire/281538198643648). 
As noted above, policing cyberspace is difficult. Indeed, Feldman et al. (2013) found that 74 percent of reported anti-Muslim prejudice occurred online, in comparison to 26 percent of offline incidents. Worryingly, critics argue that the difficult nature of policing cyberspace has therefore led to Muslim communities being failed by their local police forces in the United Kingdom. Indeed, Tell MAMA, which records antiMuslim attacks, showed that it had recorded 1,432 cases of online abuse in the last 22 months and argued that not enough was being done to investigate it (BBC News, 2013d).

The problem for the police therefore is helping root out far-right groups and lone wolf extremists who are using social networking sites like Twitter to post malicious statements (Esposito \& Kalin, 2011). This realm of cyber activism used by groups like the EDL and others who are promoting online hate means the police require more people to report what they see and what they read so that they can take the necessary actions required to either remove the online hate material or in some cases arrest and charge people. At the moment those who use online hate to disguise themselves in a cloak of anonymity remain at large because they understand that unless someone reports them they can remain anonymous.

\section{Reporting Online Islamophobia}

One of the major issues of online anti-Muslim abuse is the role of the police in dealing with an increasingly complex arena that allows many people to remain anonymous. Tell MAMA (2013), for example, actively encourages people to report these incidents. Apart from these problems, the role of the police in dealing with hate incidents offline will also have an impact on how incidents are reported online. For example, public perception of the police in tackling offline hate crime has had a significant impact upon police and Muslim community relations (BBC News, 2013d).

Historically, the policing of ethnic minorities has often been tainted by allegations of policing by stereotypes that includes racial prejudice and racial discrimination of black and Asian men (Bowling, 1999). Following the 9/11 attacks the risk is that those stereotypes have re-emerged with "over policing" of Muslim communities, who are increasingly viewed with suspicion (Awan, 2012). This has intensified with cases such as Rizwaan Sabir. Sabir, a student at the University of Nottingham, was arrested by the police for downloading an al-Qaeda training manual but released without charge. After winning damages of $£ 20,000$ from Nottinghamshire police, for false imprisonment, Sabir said: "I was very, very lucky in the sense that I was released without charge because I was innocent in the first place..." (Jones, 2011).

The Sabir case highlights how, post-9/11, the police need to be very careful about how they deal with counterterrorism cases, because old stereotypes may reemerge and may have an impact upon how Muslim communities report online abuse. A study by Awan, Blakemore, and Simpson (2013) regarding policing and Muslim community relations found that participants would often describe the police as either being "racist," "heavy-handed," "unprofessional," and having a "lack of communication and community skills." This in turn resulted in the Muslim community not reporting crime to the police because they felt a sense of mistrust. 
Indeed, core issues such as a lack of trust in the police service were also discussed by participants in the Awan et al. (2013) study, suggesting that individual experiences with the police may be a reason why the community lost trust in the police, and why some communities may not feel comfortable in reporting online abuse to the police. Counterterrorism policing operations also appeared to have a significant impact on the Muslim community's perception of the police service. For example, in Birmingham, the local community and area had been making headline news in the wake of controversial counterterrorism arrests. Project Champion and the installation of secret CCTV cameras to effectively ring-fence the Muslim community in predominately Muslim areas in Birmingham and monitor their movements was an additional reason why the community were distrustful of the police (Awan, 2012).

The problem regarding the low level of people reporting online abuse may also be due to people not being aware when an online offense has been committed. Furthermore, even if such cases are reported to the police, it is acknowledged that they have limited resources, and in many cases tracking the crime can present many problems from both a jurisdictional point of view with Internet Service Providers, to the role of free speech and the issue of online anonymity. Thus, for the police it can be like "finding a needle in a virtual haystack" (Awan \& Blakemore, 2012, p. 11). The police therefore must look to adopt different policing models, ranging from community-led policing to intelligence-led policing, in helping tackle the problem.

\section{Conclusion}

Cyber hate remains a complex problem and with the emerging rise of online antiMuslim hate, prejudice, discrimination, and threats there is an urgent need to examine this area in more depth. This article has provided a brief snapshot of the problem of online anti-Muslim abuse by examining online Islamophobia on Twitter, and suggesting that positive ways of dealing with such problems will require a multifaceted partnership approach. As a result, a new international and national online cyber hate strategy should be adopted, that highlights online anti-Muslim abuse and ways in which the police can deal with such incidents.

Perhaps a further strengthening of cyber hate regulation and protocols could also be used to tackle online threats made against people of all backgrounds, including antiMuslim abuse, and at the same time ensuring free speech is protected. Accordingly, the UK government and police service must examine all online threats and the links with actual offline violence as this could help agencies have a better understanding of what they are dealing with. The reporting of online anti-Muslim abuse must also be taken seriously; improved relations between the police and Muslim community may help to achieve that. A more robust and clearer definition of what is online Islamophobia should also be adopted.

The tweets examined in this article highlight the derogatory and systematic abuse that people are suffering as a result of online abuse. The typology created of online abusers shows that offenders presented some key characteristics and motivations behind their actions. We need to begin a process of evidence-based research to help create a safer online space for users; including innovative ways that policymakers, police forces, third sector organizations, and social networking sites (such as Twitter 
and Facebook) can best respond to online anti-Muslim hate crime. This should hopefully result in an improved dialogue between the different stakeholders and ensure that online anti-Muslim hate incidents are taken more seriously. In particular, Twitter has been criticized for a lack of real action toward online hate; hopefully this study can shed light on some important changes they and the police can make to ensure online hate crime can be dealt with in a more efficient and proactive manner.

\section{Notes}

1. See the cases of Stan Collymore (BBC News, 2014) and Caroline Criado-Perez (The Huffington Post,

2013).

2. The EDL is a UK-based far-right organization that has at its core the aim to tackle "militant Islam," and the BNP is a far-right UK political party.

\section{References}

Allen, C. 2001. Islamophobia in the Media Since September 11th, Forum Against Islamophobia and Racism.

http://www.fairuk.org/docs/islamophobia-in-the-media-since-911-christopherallen.pdf.

Allen, C. 2010. Islamophobia. London: Ashgate.

Allen, C. 2014. Findings From a Pilot Study on Opposing Dudley Mosque Using Facebook Groups as Both Site and Method for Research, Sage Open.

http://sgo.sagepub.com/content/4/1/2158244014522074.fulltext.pdfphtml.

Allport, G.W. 1954. The Nature of Prejudice. Reading, MA: Addison-Wesley.

Anti-Islam Blog. 2013. http://anti-islam.blogspot.co.uk/.

Association of Chief Police Officers. 2013. True Vision Records. http://www.reportit.org.uk/true vision_records_a_significant_weekly_reduct.

Awan, I. 2012. "The Impact of Policing British Muslims: A Qualitative Exploration." Journal of Policing, Intelligence and Counter-Terrorism 7 (1): 22-35.

Awan, I., and B. Blakemore. 2012. Policing Cyber Hate, Cyber Threats and Cyber Terrorism. Ashgate: Farnham.

Awan, I., B. Blakemore, and K. Simpson. 2013. "Muslim Communities Attitudes Towards and Recruitment into the British Police Service." International Journal of Law, Crime and Justice 41 (4): 421-37. http://dx.doi.org/10.1016/j.ijlcj.2013.08.004.

BBC News. 2013a. Al-Rahma Islamic Centre Destroyed in "Hate Crime" Fire. http://www.bbc.co.uk/news/uk-england-london-22785074.

BBC News. 2013b. Woolwich Aftermath: Key Facts. http://www.bbc.co.uk/news/uk22635318. 
BBC News. 2013c. 632 Anti-Muslim Hate Incidents Recorded by Tell Mama. http://www.bbc.co.uk/news/uk-21712826.

BBC News. 2013d. Police Failing to Investigate Anti-Muslim Abuse. http://www.bbc.co.uk/news/uk-25057246.

BBC News. 2014. Ex-Footballer Collymore Accuses Twitter Over Abusive Messages. http://www.bbc.co.uk/news/uk-25838114.

Birmingham Mail. 2013. Death Threats Made to Salma Yaqoob After Question Time Appearance. http://www.birminghammail.co.uk/news/local-news/death-threats-mademuslim-politician-4219595.

Blakemore, B. 2013. "Extremist Groups and Organisations." In Extremism, CounterTerrorism and Policing, eds. I. Awan and B. Blakemore. Ashgate: Farnham, 87-102.

Bowling, B. 1999. Violent Racism: Victimisation, Policing and Social Context, Revised edition. Oxford: Oxford University Press.

Bunglawala, I. 2012. "Online Racist Abuse: We've All Suffered It." The Guardian. http://www.theguardian.com/commentisfree/2012/jul/11/online-racist-abuse-writersface.

Cole, J., and B. Cole. 2009. Martyrdom: Radicalisation and Terrorist Violence Among British Muslims.London: Pennant Books.

Chan, J.B.L. 2007. "Police and New Technologies." In Handbook of Policing, ed. T. Newburn.Cullompton: Willan Publishing, 655-79.

Christopherson, K. 2007. "The Positive and Negative Implications of Anonymity in Internet, Nobody Knows You're a Dog." Computers in Human Behavior 23 (6): 303856.

Coliandris, G. 2012. "Hate in a Cyber Age." In Policing Cyber Hate, Cyber Threats and Cyber Terrorism, eds. I. Awan and B. Blakemore. Ashgate: Farnham, 75-94.

Crown Prosecution Service. 2014. Guidelines on Prosecuting Cases Involving Communications Sent via Social Media.

http://www.cps.gov.uk/legal/a to c/communications sent via social media/.

DEMOS Report. 2011. The Rise of Populism in Europe Can Be Traced Through Online Behaviour. http://www.demos.co.uk/files/Demos OSIPOP Bookweb 03.pdf?1320601634.

Douglas, K., C. McGarty, A.M. Bliuc, and G. Lala. 2005. "Understanding Cyberhate: Social Competition and Social Creativity in Online White Supremacist Groups." Social Science Computer Review 23 (1): 68-76. 
Esposito, L.J., and I. Kalin. 2011. Islamophobia: The Challenge of Pluralism in the 21st Century. New York: Oxford University Press.

Feldman, M., M. Littler, J. Dack, and N. Copsey. 2013. Anti-Muslim Hate Crime and the Far Right. Teeside University.

http://tellmamauk.org/wpcontent/uploads/2013/07/antimuslim2.pdf.

Forum Against Islamophobia and Racism. 2013.

http://www.fairuk.org/introduction.htm.

Greenwood, C. 2013. "Stop Tip-Toeing Around Race of Grooming Gangs, Say MPs: Committee Says Police and Prosecutors Must be Able to Raise Issue Without Being Accused of Racism." Mail Online. http://www.dailymail.co.uk/news/article-

2338640/Stop-tip-toeing-race-grooming-gangssay-

MPs-Committee-says-police-prosecutors-able-raise-issue-accused-racism.html.

Hall, N. 2005. Hate Crime. Cullompton: Willan Publishing.

Hasan, M. 2012. "We Mustn't Allow Muslims in Public Life to be Silenced." The Guardian. http://www.theguardian.com/commentisfree/2012/jul/08/muslims-publiclife-abuse.

Iganski, P. 2012. Hate Crime: Taking Stock: Programmes for Offenders of Hate. Belfast: Northern Ireland Association for the Care and Resettlement of Offenders.

JihadWatch. 2013. http://www.jihadwatch.org/.

Jones, S. 2011. "Student in AI Qaida Raid Paid $£ 20,000$ by Police." The Guardian. http://www.theguardian.com/uk/2011/sep/14/police-pay-student-damages-al-qaida.

Larsson, G. 2007. "Cyber-Islamophobia? The Case of Wikilslam." Contemporary Islam 1 (1): 53-67.

Leveson Inquiry. 2012. Culture, Practice and Ethics of the Press.

http://www.levesoninquiry.org.uk/about/the-report/.

Online Hate Prevention Centre. 2013. Islamophobia on the Internet: The Growth of Online Hate Targeting Muslims. http://ohpi.org.au/islamophobia-on-the-internet-thegrowth-of-online-hate-targetingmuslims/.

Perry, B. 2001. "In the Name of Hate: Understanding Hate Crimes." London: Routledge.

Saul, H. 2013. "Police Call Home-Made Bomb Outside Walsall's Ashia Mosque a 'Hate Crime' and Draft in Counter-Terror Police." The Independent. http://www.independent.co.uk/news/uk/crime/police-call-homemade-bomb-outsidewalsalls-ashia-mosque-a-hate-crime-and-draft-incounterterror-police-8670548.html.

Sayyed, S., and A. Vakil. 2011. Thinking Through Islamophobia: Global Perspectives. London: Hurst \& Co. 
Sinha, K. 2013. "Anti-Muslim Sentiments on Rise in UK: British Minister." The Times of India. http://articles.timesofindia.indiatimes.com/2013-05-

22/uk/39444735_1_muslim-women-hate-crime-sayeedawarsi.

Taras, R. 2012. Xenophobia and Islamophobia in Europe. Edinburgh: Edinburgh University Press.

Tell MAMA. 2013. Anti-Muslim Hate Crime. http://tellmamauk.org/.

Tell MAMA. 2014. Analysing the Lexicon of Anti-Muslim Prejudice. http://tellmamauk.org/analysingthe-lexicon-of-anti-muslim-prejudice/.

The Guardian. 2013. UK Anti-Muslim Hate Crime Soars, Police Figures Show. http://www.theguardian.com/society/2013/dec/27/uk-anti-muslim-hate-crime-soars.

The Huffington Post. 2013. Twitter Rape Abuse of Caroline Criado-Perez Leads to Boycott Threat. http://www.huffingtonpost.co.uk/2013/07/27/twitter-rapeabuse n 3663904.html

The Runnymede Trust. 1997. Islamophobia: A Challenge for Us All. http://www.runnymedetrust.org/ uploads/publications/pdfs/islamophobia.pdf.

True Vision. 2013. Internet Hate Crime.

http://www.reportit.org.uk/reporting_internet_hate_crime.

Urquhart, C. 2013. "Attacks on Muslims Soar in Wake of Woolwich Murder." The Guardian. http://www.theguardian.com/uk/2013/may/25/woolwich-murder-attacks-onmuslims.

Waddington, P.A.J. 2010. “An Examination of Hate Crime.” Police Review, 118 (6077): 14-5.

Wall, D., ed. 2001. Crime and the Internet. London: Routledge.

Weaver, S. 2013. "A Rhetorical Discourse Analysis of Online Anti-Muslim and AntiSemitic Jokes." Ethnic and Racial Studies 36 (3): 483-99.

Whine, M. 2003. "Far Right Extremists on the Internet." In Cyber Crime: Law Enforcement, Security and Surveillance in the Information Age, eds. D. Thomas and B. Loader. London: Routledge, 234-50 